Article

\title{
A Redox-Switchable Colorimetric Probe for "Naked-Eye" Detection of Hypochlorous Acid and Glutathione
}

\author{
Qian Han ${ }^{1,2,+}$, Fang Zhou ${ }^{1,+}$, Yue Wang ${ }^{1}$, Huan Feng ${ }^{1}$, Qingtao Meng ${ }^{1, *}$, Zhiqiang Zhang ${ }^{1, *}$ \\ and Run Zhang ${ }^{1,3, *(D)}$ \\ 1 School of Chemical Engineering, University of Science and Technology Liaoning, Anshan, \\ Liaoning 114051, China \\ 2 School of Chemistry and Life Science, Anshan Normal University, Anshan 114007, China \\ 3 Australian Institute for Bioengineering and Nanotechnology, The University of Queensland, \\ Brisbane 4072, Australia \\ * Correspondence: qtmeng@ustl.edu.cn (Q.M.); zhangzhiqiang@ustl.edu.cn (Z.Z.); r.zhang@uq.edu.au (R.Z.); \\ Tel.: +86-412-5929627 (Q.M.); +61-7-33463806 (R.Z.) \\ $\dagger$ These authors contributed equally to this work and they should be regarded as co-first authors.
}

Academic Editors: Run Zhang, D. Amilan Jose, Hang Thu Ta and Mingqian Tan

Received: 30 May 2019; Accepted: 3 July 2019; Published: 4 July 2019

\begin{abstract}
We report the development of a new colorimetric probe (L-ol) for investigations of the redox process regulated by hypochlorous acid $(\mathrm{HOCl})$ and glutathione $(\mathrm{GSH})$. The $\mathrm{HOCl} / \mathrm{GSH}$ redox-switching cycle process was investigated in detail by UV-vis absorption spectroscopy, colorimetric analysis assay and high-resolution mass spectrometry (HRMS). The switchable absorbance responses were attributed to the $\mathrm{HOCl}$-induced oxidation of the $p$-methoxyphenol unit to the benzoquinone derivative (L-one) and sequential reduction of L-one to hydroquinone (L-ol') by GSH. In phosphate-buffered saline (PBS) buffer, the absorbance of L-ol at $619 \mathrm{~nm}$ underwent a remarkable bathochromic-shift, accompanied by a color change from pale yellow to blue in the presence of $\mathrm{HOCl}$. With further addition of GSH, the absorbance of L-one exclusively recovered to the original level. Meanwhile, the blue-colored solution returned to the naive pale yellow color in the presence of GSH. The detection limits for $\mathrm{HOCl}$ and GSH were calculated to be 6.3 and $96 \mathrm{nM}$ according to the IUPAC criteria. Furthermore, L-ol-loaded chromatography plates have been prepared and successfully applied to visualize and quantitatively analyze $\mathrm{HOCl}$ in several natural waters.
\end{abstract}

Keywords: redox-switchable; hypochlorous acid; glutathione; colorimetric; detection; water samples

\section{Introduction}

The redox balance between reducing and oxidizing species is important in the regulation of a signal pathway in biosystems. The redox process is normally achieved by a series of elaborate mechanisms [1-4]. The reduction-oxidation state of the cell is primarily a consequence of the precise balance between the levels of reactive oxygen species (ROS) and antioxidant [5-8]. Among these ROS, hypochlorous acid $(\mathrm{HOCl})$ is an endogenous microbicidal agent and a highly potent oxidant that is mainly generated by the catalysis of myeloperoxidase (MPO) in the presence of chloride and hydrogen peroxide under physiological conditions [9-11]. Owing to the strong oxidizing effect, $\mathrm{HOCl}$ could defend against the invasion of bacteria and regulate the life cycle of the cell [12]. Nevertheless, the excessive or misplaced production of $\mathrm{HOCl}$ in living systems may lead to extensive oxidative stress and oxidative damage, which can induce serious diseases such as arthritis, cardiovascular diseases, atherosclerosis, neuron degeneration, and cancer [13-17]. Glutathione (GSH) is the most abundant non-protein biothiol in mammalian cells, which was considered to be the main player in combating 
oxidative stress and regulating the redox environment of the internal cellular compartments [18-23]. Variations in GSH concentration have been linked to many pathological processes including cancer, aging, and diabetes [24-27]. It is reported that endogenous GSH was found to protect cells from the damage caused by $\mathrm{HOCl}$ [28]. Therefore, much effort has been focused on the development of effective detection methods for visualizing or monitoring the redox cycle between $\mathrm{HOCl}$ and GSH, which will be beneficial for fully understanding and treating numerous pathological diseases [29-33]. In comparison with other technologies, organic colorimetric probes are desirable for detecting various kinds of highly reactive species such as $\mathrm{HOCl}$ and GSH, owing to their high sensitivity, excellent selectivity, real-time analysis and in situ observation [34].

Although increasing amounts of molecular probes for $\mathrm{HOCl}$ and GSH detection have been reported, only few of them have been applied to monitor the redox changes mediated by $\mathrm{HOCl}$ and antioxidants, such as GSH, simultaneously [35-38]. In this work, a novel redox-switchable molecular probe, L-ol was designed and synthesized by introduction of $p$-methoxyphenol as a redox response unit. It is reported that $p$-methoxyphenol can be selectively oxidized to benzoquinone by $\mathrm{HOCl}$ [39-43]. After further treatment of the obtained $p$-benzoquinone (L-one) by glutathione (GSH) [44], a new reduced product of L-ol' was obtained (Scheme 1). In addition, the redox process was accompanied by a visual pale yellow to blue to pale yellow color change, which is consistent with the UV-vis spectra. Furthermore, L-ol-based test plates have been successfully prepared for the visualization and quantitative analysis of $\mathrm{HOCl}$ in natural water.

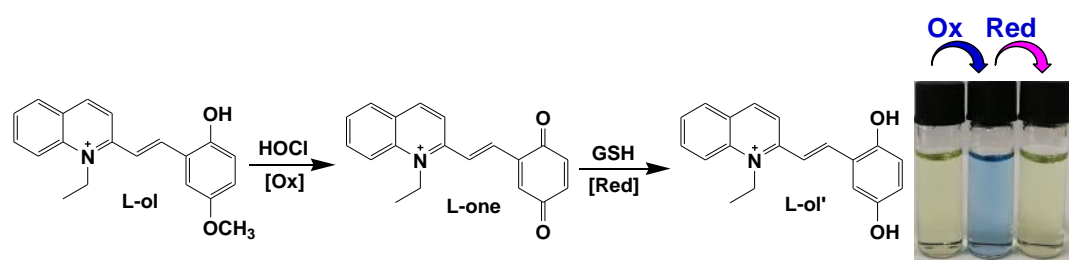

Scheme 1. The redox-switchable behaviors of L-ol regulated by hypochlorous acid $(\mathrm{HOCl})$ and glutathione (GSH).

\section{Results and Discussion}

\subsection{Design, Synthesis and Characterization of the Molecular Probe}

L-ol was synthesized by one-step condensation reaction between 1-ethyl-2-methylquinolinium iodide and 2-hydroxy-5-methoxy benzaldehyde in the presence of a catalytic amount of piperidine (2 drops) in methanol (Scheme 2). The chemical structure of L-ol was characterized by ${ }^{1} \mathrm{H}$ NMR, ${ }^{13} \mathrm{C}$ NMR and high-resolution mass spectrometry (HRMS) (Figure S1-3). Absorbance of L-ol in aqueous media (dimethylformamide (DMF):phosphate-buffered saline (PBS) =7:3, $20 \mathrm{mM}, \mathrm{pH}=7.4$ ) was not changed within $24 \mathrm{~h}$ (Figure S4), indicating the high optical stability of L-ol under the test condition.

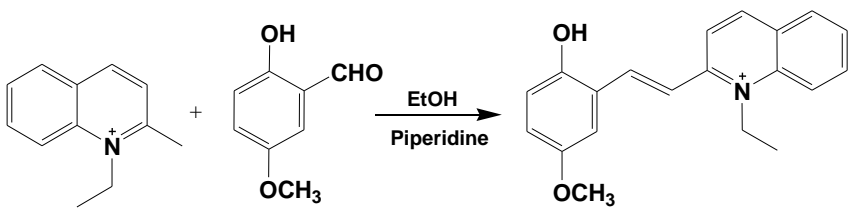

Scheme 2. Synthetic procedure of L-ol.

The HOCl/GSH regulated redox-switching process was first monitored by the HRMS. As shown in Figure S3, the peak at 306.1484 was obtained as the molecular ion peak of [L-ol] ${ }^{+}$(calcd. 306.1489). Upon addition of $\mathrm{HOCl}$ into the aqueous solution of $\mathbf{L - o l}$, the peak at $\mathrm{m} / \mathrm{z}=306.1484$ disappeared and a new molecular ion peak emerged which can be assigned to $p$-benzoquinone derivative (L-one) at $\mathrm{m} / \mathrm{z}=290.1173$ (Figure S5). After further treatment of the generated L-one with GSH, the appearance 
of the peak at $\mathrm{m} / \mathrm{z}=292.1328$ indicated the generation of the reduced product of $\mathbf{L}-$-ol' $^{\prime}$ (Figure S6). The HRMS titration analysis confirmed the proposed redox-switchable behaviors of $\mathbf{L}-\mathbf{o l}$ regulated by $\mathrm{HOCl}$ and GSH (Scheme 1).

\subsection{Oxidation of L-ol by HOCl and UV-vis Spectra Studies}

Upon addition of increasing amounts of $\mathrm{HOCl}, \mathrm{UV}$-vis absorption spectra of L-ol in PBS aqueous buffer (DMF:PBS = 7:3, $20 \mathrm{mM}$, pH = 7.4) were recorded. As shown in Figure 1, free L-ol exhibited strong absorption band centred at $366 \mathrm{~nm}$ and $435 \mathrm{~nm}\left(\log \varepsilon_{1}=3.50\right)$. Upon the addition of $\mathrm{HOCl}$, the two peaks decreased notably and an intense absorption band centred at $619 \mathrm{~nm}$ appeared $\left(\log \varepsilon_{2}=4.36\right)$. The new absorption was attributed to the oxidation of the $p$-methoxyphenol to the corresponding benzoquinone derivative (L-one) [45]. Absorbance at $619 \mathrm{~nm}$ became constant when the concentration of $\mathrm{HOCl}$ was $>40 \mu \mathrm{M}$ (Figure 1, inset (B)). Three clear isosbestic points were found to be at 378, 404 and $496 \mathrm{~nm}$, which indicated the quantitative reaction of $\mathbf{L}-\mathrm{ol}$ with $\mathrm{HOCl}$. In agreement with the obvious bathochromic-shift changes for $\mathbf{L}-\mathbf{o l}$ after introducing $\mathrm{HOCl}$, the color of the $\mathbf{L}$-ol solution changed from pale yellow to blue (Figure 1, inset (A)). Obvious color changes of the solution suggest that L-ol can serve as a potential "naked-eye" indicator for $\mathrm{HOCl}$ detection in water samples. In addition, the absorbance at $619 \mathrm{~nm}$ of L-ol exhibited a good linear relationship with the concentration of $\mathrm{HOCl}$ $(2.5-25.0 \mu \mathrm{M})$ (Figure S7). According to the IUPAC criteria (LOD $=3 \sigma / \mathrm{k})$, the detection limit (LOD) was calculated to be $6.3 \mathrm{nM}$.

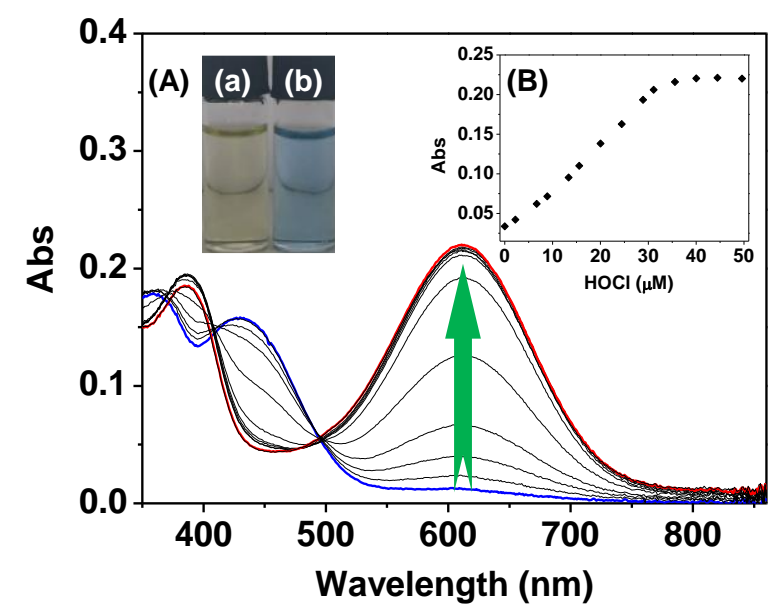

Figure 1. UV-vis absorption spectra of $\mathbf{L}-\mathbf{o l}(10 \mu \mathrm{M})$ in the presence of different amounts of $\mathrm{HOCl}$ $(0-50 \mu \mathrm{M})$ in phosphate-buffered saline (PBS) aqueous buffer (dimethylformamide (DMF):PBS = 7:3, $20 \mathrm{mM}, \mathrm{pH}=7.4$ ). Inset: A. Colorimetric changes of $\mathbf{L}-\mathbf{o l}$ in the (a) absence and (b) presence of $\mathrm{HOCl} ; \mathrm{B}$. Plot of the absorbance at $619 \mathrm{~nm}$ of $\mathbf{L - o l}$ against the concentration of $\mathrm{HOCl}$.

It has been found that $p$-methoxyphenol was stable toward most other common ROS [46]. The selectivity of $\mathbf{L}$-ol towards $\mathrm{HOCl}$ over other competitive $\mathrm{ROS}\left({ }^{1} \mathrm{O}_{2}, \mathrm{ONOO}^{-}, \bullet \mathrm{OH}, \mathrm{H}_{2} \mathrm{O}_{2}\right)$, anions $\left(\mathrm{Br}^{-}, \mathrm{AcO}^{-}, \mathrm{Cl}^{-}, \mathrm{F}^{-}, \mathrm{HSO}_{3}{ }^{-}, \mathrm{HSO}_{4}{ }^{-}, \mathrm{S}^{2-}, \mathrm{NO}_{2}{ }^{-}, \mathrm{NO}_{3}{ }^{-}, \mathrm{PO}_{4}{ }^{2-}, \mathrm{SO}_{3}{ }^{2-}, \mathrm{SO}_{4}{ }^{2-}, \mathrm{HCO}_{3}{ }^{-}, \mathrm{OH}^{-}, \mathrm{Pi}, \mathrm{PPi}\right)$ and biothiols (Cys, Hcy and GSH) were investigated by UV-vis absorption spectra. The change in the absorption spectra was found to be specific towards $\mathrm{HOCl}$. Significant changes in the absorption spectra were not observed upon addition of the aforementioned competitive species (Figure S8). In addition, addition of 1.0 equiv. of $\mathrm{HOCl}$ to the above solution led to the increase of absorbance, and the increased absorbance was similar to the one of the addition of 1.0 equiv. of $\mathrm{HOCl}$ alone to L-ol solution (Figure 2). These observations indicate that the $\mathrm{HOCl}$-specific responses were not disturbed by competitive species. 


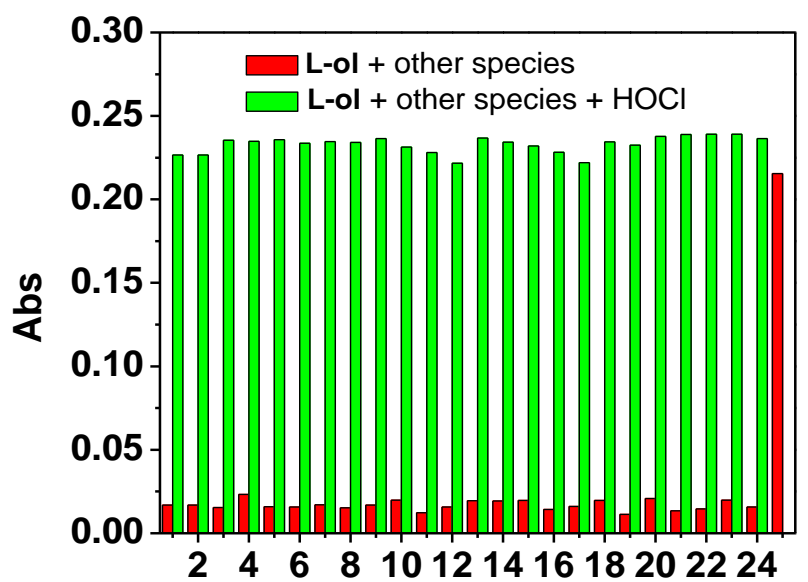

Figure 2. Absorption spectra responses of $\mathbf{L}-\mathbf{o l}(10 \mu \mathrm{M})$ towards various competitive species $(50 \mu \mathrm{M})$ in PBS aqueous buffer (DMF:PBS = 7:3, $20 \mathrm{mM}, \mathrm{pH}=7.4$ ). 1. $\mathrm{Br}^{-}, 2 . \mathrm{AcO}^{-}, 3 . \mathrm{Cl}^{-}, 4 . \mathrm{F}^{-}, 5 . \mathrm{HSO}_{3}^{-}, 6$. $\mathrm{HSO}_{4}{ }^{-}, 7 . \mathrm{S}^{2-}, 8 . \mathrm{NO}_{2}{ }^{-}, 9 . \mathrm{NO}_{3}{ }^{-}, 10 . \mathrm{OH}^{-}, 11 . \mathrm{PO}_{4}{ }^{2-}, 12 . \mathrm{SO}_{3}{ }^{2-}, 13 . \mathrm{HCO}_{3}{ }^{-}, 14 . \mathrm{Pi}, 15 . \mathrm{PPi}, 16 . \mathrm{HOCl}$, 17. ${ }^{1} \mathrm{O}_{2}, 18$. $\mathrm{ONOO}^{-}, 19$. $\mathrm{OH}, 20 . \mathrm{H}_{2} \mathrm{O}_{2}$, 21. Cys, 22. Hcy, 23. GSH, 24. mixed competitive species, 25. $\mathrm{HOCl}$.

The specificity of $\mathbf{L}-\mathbf{o l}$ to $\mathrm{HOCl}$ was also confirmed by a "naked-eye" colorimetric assay. The color of L-ol solution specifically changed from pale yellow to blue with the titration of $\mathrm{HOCl}$, while distinct color changes were not found upon addition of other biological species including ROS, anions and biomolecules (Figure 3). The results of colorimetric analysis suggest that $\mathbf{L - o l}$ can be employed as a specific probe for "naked-eye" discrimination of $\mathrm{HOCl}$ without any spectroscopic instrumentation.

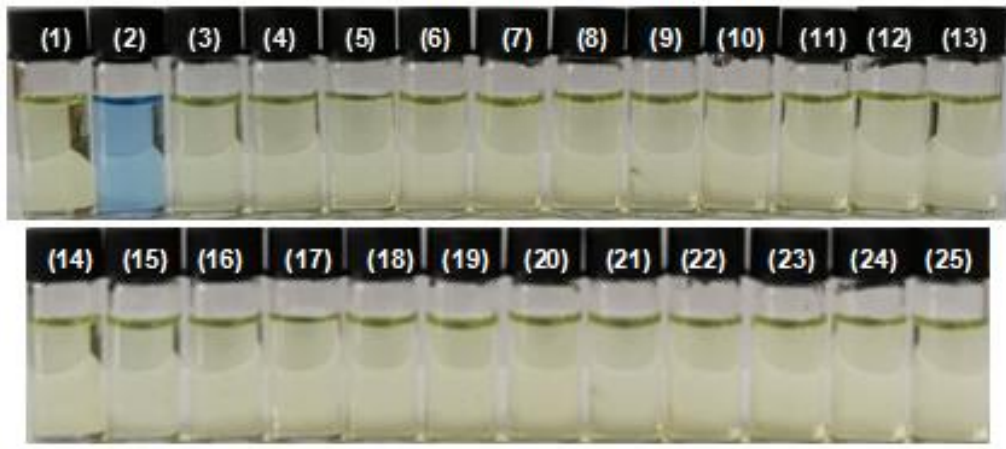

Figure 3. The color changes of L-ol $(10 \mu \mathrm{M})$ towards various competitive species $(50 \mu \mathrm{M})$ in PBS aqueous buffer (DMF:PBS = 7:3, $20 \mathrm{mM}, \mathrm{pH}=7.4$ ). 1. Free L-ol, 2. $\mathrm{HOCl}, 3 . \mathrm{Br}^{-}, 4 . \mathrm{AcO}^{-}, 5 . \mathrm{Cl}^{-}, 6 . \mathrm{F}^{-}$, 7. $\mathrm{HSO}_{3}{ }^{-}, 8 . \mathrm{HSO}_{4}{ }^{-}, 9 . \mathrm{S}^{2-}, 10 . \mathrm{NO}_{2}{ }^{-}, 11 . \mathrm{NO}_{3}{ }^{-}, 12 . \mathrm{OH}^{-}, 13 . \mathrm{PO}_{4}{ }^{2-}, 14 . \mathrm{SO}_{3}{ }^{2-}, 15 . \mathrm{HCO}_{3}{ }^{-}, 16 . \mathrm{Pi}, 17$. $\mathrm{PPi}, 18$. $\mathrm{HOCl}, 19 .{ }^{1} \mathrm{O}_{2}, 20 . \mathrm{ONOO}^{-}$, 21. $\mathrm{OH}, 22 . \mathrm{H}_{2} \mathrm{O}_{2}$, 23. Cys, 24. Hcy, 25. GSH.

\subsection{Reduction of L-one by GSH and UV-vis Spectra Studies}

The reduction process of the obtained L-one in the presence of GSH was also evaluated by recording the changes of the corresponding UV-Vis absorption spectra. After further treatment of L-one with GSH in phosphate buffer $(20 \mathrm{mM}, \mathrm{pH}=7.4)$, the absorption band at $619 \mathrm{~nm}$ was decreased gradually $\left(\log \varepsilon_{3}=3.24\right)$, accompanied with the increase of the absorption band at $435 \mathrm{~nm}$ (Figure 4). The final absorption spectrum is almost identical to the one of that of L-ol under identical conditions, suggesting that the hydroquinone $\left(\mathbf{L}-\mathbf{o l}^{\prime}\right)$ was quantitatively obtained in the presence of GSH. Furthermore, the solution of L-one recovered to be pale yellow color (Figure 4, inset). After the GSH reduction process, the recovery of the absorption spectra and the color of the solution can be easily observed by the naked eye. Corresponding changes in UV-vis absorbance of L-one are linearly 
proportional to the concentration of GSH in the range of 0-60 $\mu \mathrm{M}$ (Figure S9). The detection limit for GSH was calculated to be $96 \mathrm{nM}$ according to the methods defined by IUPAC.

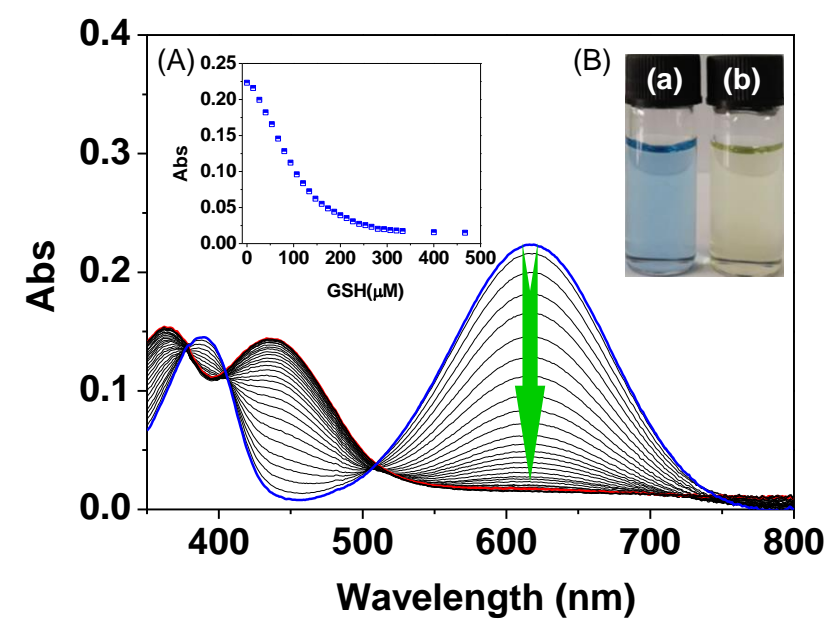

Figure 4. UV-vis absorption spectra of L-one $(10 \mu \mathrm{M})$ in the presence of different amounts of GSH $(0-500 \mu \mathrm{M})$ in PBS aqueous buffer (DMF:PBS = 7:3, $20 \mathrm{mM}, \mathrm{pH}=7.4)$. Inset: (A) Plot of the absorbance at $617 \mathrm{~nm}$ of L-one against the concentration of GSH; (B) Colorimetric changes of L-one in the (a) absence and (b) presence of GSH.

To further explore the reduction specificity of $\mathbf{L}$-one to GSH in the presence of competitive species, the absorbance responses towards several amino acids, biothiols and anions, such as Leu, His, Val, Tyr, Gerl, Try, Phe, Leu, Thr, Lys, Gly, Pro, Ary, Gln, Asn, Asp, Ala, Met, Hcy, Cys, $\mathrm{S}^{2-}, \mathrm{HSO}_{4}{ }^{-}, \mathrm{HSO}_{3}{ }^{-}$, $\mathrm{SO}_{4}{ }^{2-}, \mathrm{SO}_{3}{ }^{2-}$ and ascorbic acid (Vc) were investigated. As shown in Figure S10, the absorption peak of L-one centered at $619 \mathrm{~nm}$ remarkably decreased upon addition of GSH, while only a small decrease of the absorbance of L-one was observed upon addition of Met and Vc. An obvious decrease of the UV-vis absorption was not observed in the presence of other competitive species. In addition, the absorbance response of $\mathbf{L}$-one towards GSH in the presence of other interfering species is nearly identical to that in the absence of these species (Figure 5). The results illustrated that L-one does have a specific response toward GSH over other common interfering species. The GSH-specific reduction process of L-one was also tested by colorimetric assay with a verity of competitive species. Upon addition of GSH, the solution color of L-one recovered to pale yellow from blue, while negligible color changes were found for the L-one solution in the presence of Met and Vc. The specific response of GSH over Met and $\mathrm{Vc}$ is attributed to the powerful reducibility of GSH [35]. Moreover, no obvious solution color changes were noticed upon addition of other competitive amino acids, biothiols and anions, further indicating that L-one was specifically reduced by GSH (Figure S11). 


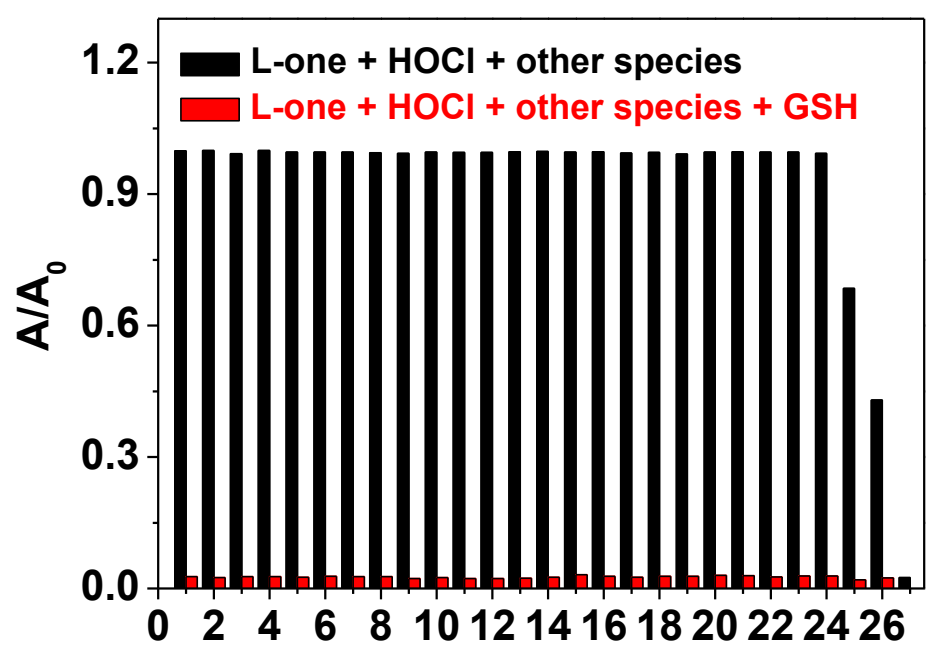

Figure 5. UV-vis absorption spectra of L-one $(10 \mu \mathrm{M})$ in the presence of various analytes $(500 \mu \mathrm{M})$ in PBS aqueous buffer (DMF:PBS = 7:3, $20 \mathrm{mM}, \mathrm{pH}=7.4$ ): 1. Leu, 2. His, 3. Val, 4. Tyr, 5. Gerl, 6. Try, 7. Phe, 8. Leu, 9. Thr, 10. Lys, 11. Gly, 12. Pro, 13. Ary, 14. Gln, 15. Asn, 16. Asp, 17. Ala, 18. Hcy, 19. Cys, 20. $\mathrm{S}^{2-}, 21 . \mathrm{HSO}_{4}{ }^{-}, 22 . \mathrm{HSO}_{3}{ }^{-}, 23 . \mathrm{SO}_{4}{ }^{2-}, 24 . \mathrm{SO}_{3}{ }^{2-}, 25 . \mathrm{Met}, 26, \mathrm{Vc}, 27 . \mathrm{GSH}$.

Reversible regulation of the redox-switching process was then examined by alternate addition of $\mathrm{HOCl}$ and GSH into the solution of L-ol in PBS aqueous buffer. As shown in Figure 6, the absorbance of L-ol gives rise to a switchable change at $619 \mathrm{~nm}$. Such a reversible absorbance increase/decrease of L-ol could be repeated at least 6 times. Simultaneously, the redox process was accompanied by a visual pale yellow to blue to pale yellow color change cycle (Figure 6, inset), which is consistent with the absorbance response. The time-dependent redox cycle of $\mathbf{L}-o$ l regulated by $\mathrm{HOCl} / \mathrm{GSH}$ was then investigated. As shown in Figure 7, upon the addition of $\mathrm{HOCl}$, absorbance at $619 \mathrm{~nm}$ of L-ol was rapidly increased and reached the maximum value within $1 \mathrm{~s}$, and then kept at a steady level. When another amount of $\mathrm{HOCl}$ was added, absorbance was increased rapidly again and reached another plateau rapidly. In addition, the reduction process of L-one towards GSH was also completed within $1 \mathrm{~s}$. The results indicate that $\mathrm{L}-\mathrm{ol}$ could be used to monitor the $\mathrm{HOCl} / \mathrm{GSH}$ regulated redox-switching process in real-time.

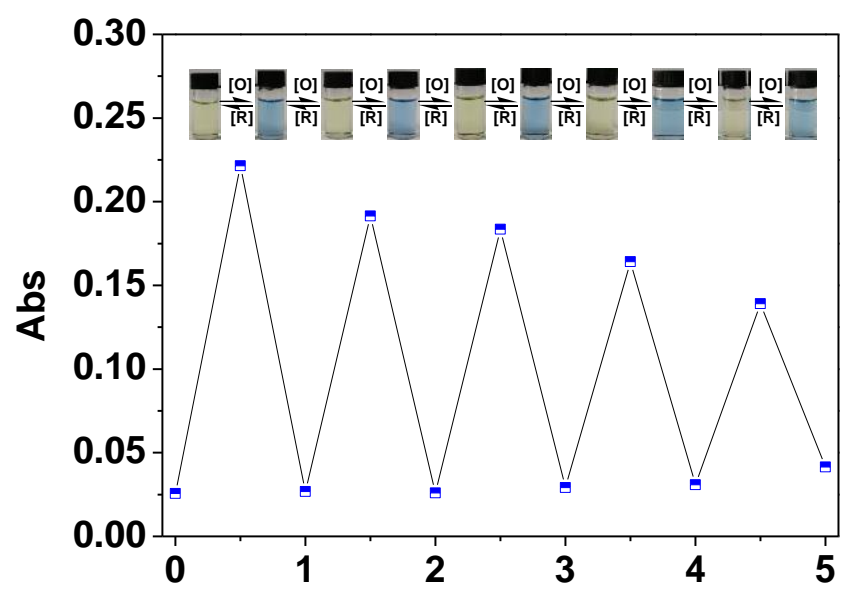

Figure 6. UV-vis absorption spectra changes at $619 \mathrm{~nm}$ of L-ol $(10 \mu \mathrm{M})$ in PBS aqueous buffer (DMF:PBS $=7: 3,20 \mathrm{mM}, \mathrm{pH}=7.4)$ upon the alternate addition of $\mathrm{HOCl} / \mathrm{GSH}$ with several concentration ratios (0:0, 20:0, 20:50, 40:50, 40:100, 60:100, 80:100, 80:150, 100:150, 120:150 and 120:200 $\mu \mathrm{M}$, respectively). [O], oxidation; [R], reduction. 


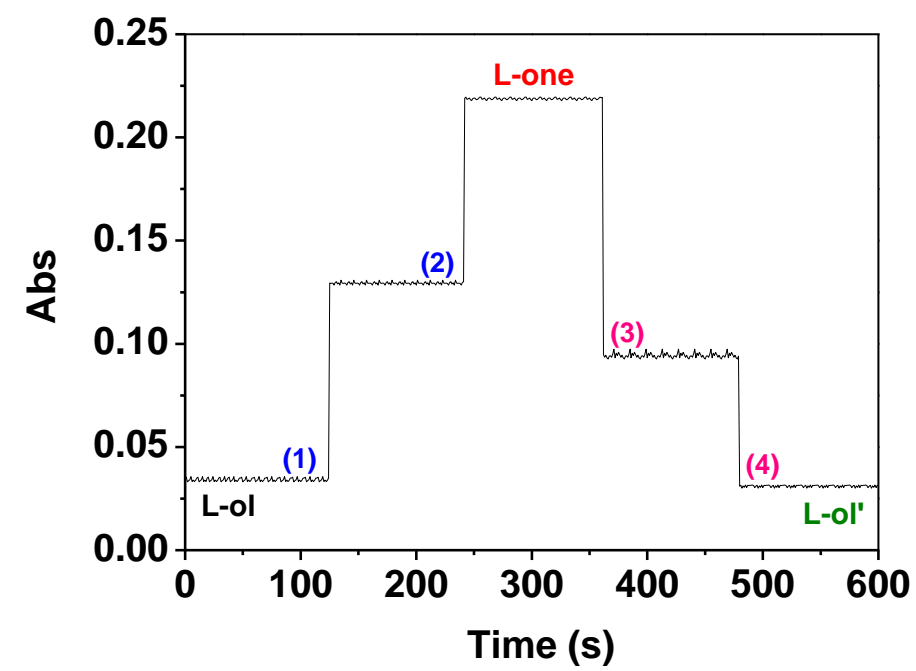

Figure 7. Time course UV-vis absorption response of L-ol (10 $\mu \mathrm{M})$ to (1) $20 \mu \mathrm{M}$, (2) $50 \mu \mathrm{M} \mathrm{HOCl}$, and in-situ formed L-one to (3) $100 \mu \mathrm{M}$ (4) $500 \mu \mathrm{M}$ GSH in PBS aqueous buffer (DMSO: $\mathrm{H}_{2} \mathrm{O}=9: 1,20 \mathrm{mM}$, $\mathrm{pH}=7.4)$.

The $\mathrm{pH}$-dependent absorbance behavior of L-ol was also explored. As shown in Figure 8, in the absence of $\mathrm{HOCl}$, L-ol emerges weak absorbance of $619 \mathrm{~nm}$ over the whole $\mathrm{pH}$ range investigated. In the assessment of $\mathrm{pH}$ responses of $\mathbf{L - o l}$ in the presence of $\mathrm{HOCl}$, it was found that the absorbance of L-ol at $619 \mathrm{~nm}$ was $\mathrm{pH}$ independent in the range of 3.0-11.5. The results indicated that L-ol feature high tolerance in a wide $\mathrm{pH}$ range.

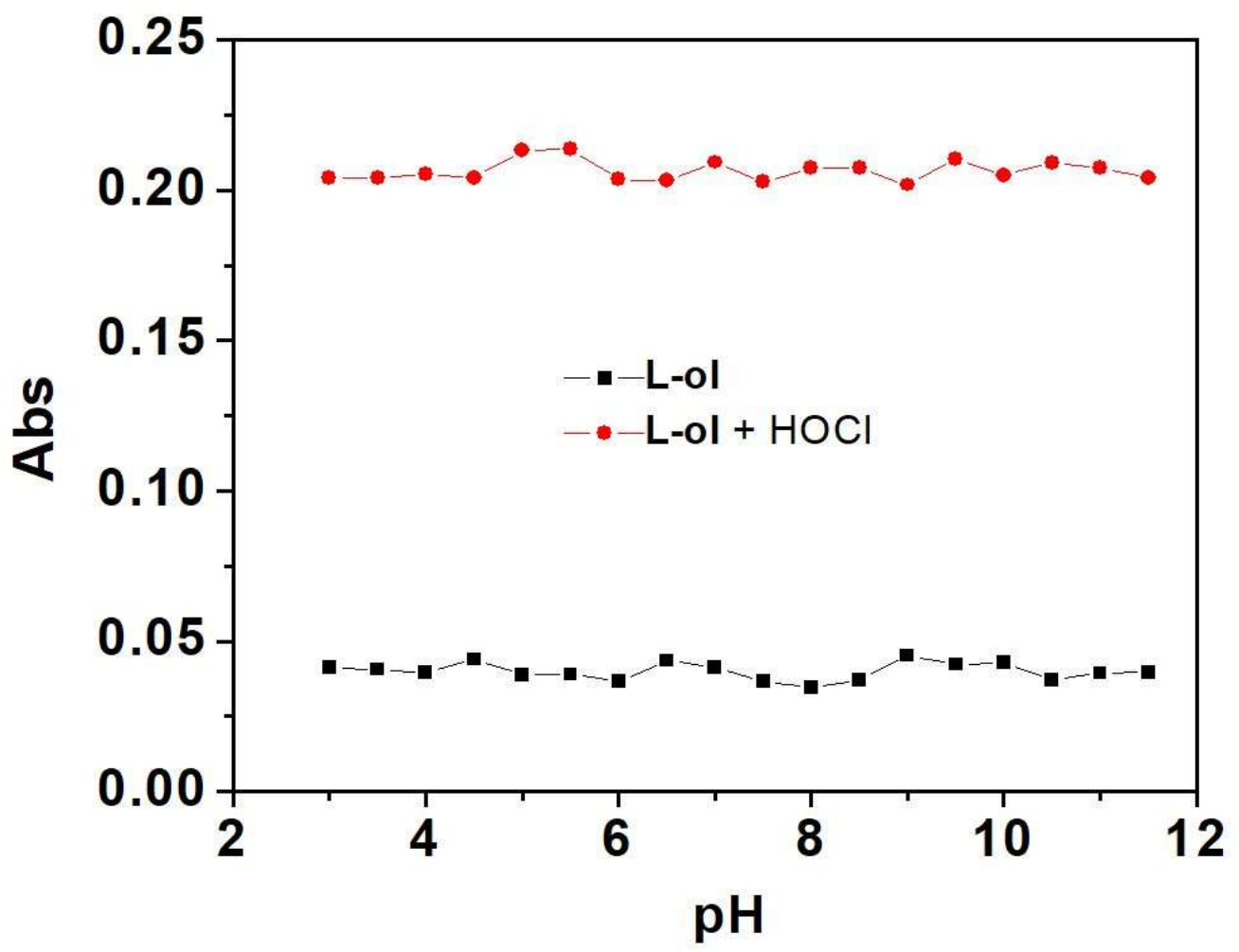

Figure 8. Effect of $\mathrm{pH}$ on the absorbance of $\mathbf{L - o l}(10 \mu \mathrm{M})$ at $619 \mathrm{~nm}$ in the absence and presence of $\mathrm{HOCl}(50 \mu \mathrm{M})$. 
2.4. Application of L-ol-Loaded Chromatography Plates in the Quantitative Analysis of $\mathrm{HOCl}$ in Natural Water Samples

$\mathrm{HOCl}$ is widely used in our daily life, such as in the disinfection of drinking water. High concentrations of $\mathrm{HOCl}$ used in water treatments is a potential health threat to human and animal lives [47]. Therefore, it is of great significance to monitor the level of $\mathrm{HOCl}$ in environmental samples in real time. Accordingly, L-ol-coated chromatography plates were prepared for the "naked-eye" quantitative analysis of $\mathrm{HOCl}$ in several water samples. As shown in Figure 9, after being exposed to different concentrations of $\mathrm{HOCl}(0-0.5 \mathrm{mM})$ in distilled water, the L-ol-coated chromatography plates presented immediately a color change from pale yellow to blue under sunlight. Next, the performances of L-ol-coated test plates for the detection of $\mathrm{HOCl}$ in potential practical water samples, such as Qianshan Spring water, NONGFU SPRING water and Anshan tap water. It has been found that similar color changes were observed for the water samples containing various amounts of $\mathrm{HOCl}$. Clearly, the test plates can detect $\mathrm{HOCl}$ in an aqueous solution at a low limit of about $0.01 \mathrm{mM}$, indicating the potential application for quantitative analysis of $\mathrm{HOCl}$ levels without any spectroscopic instrumentation.

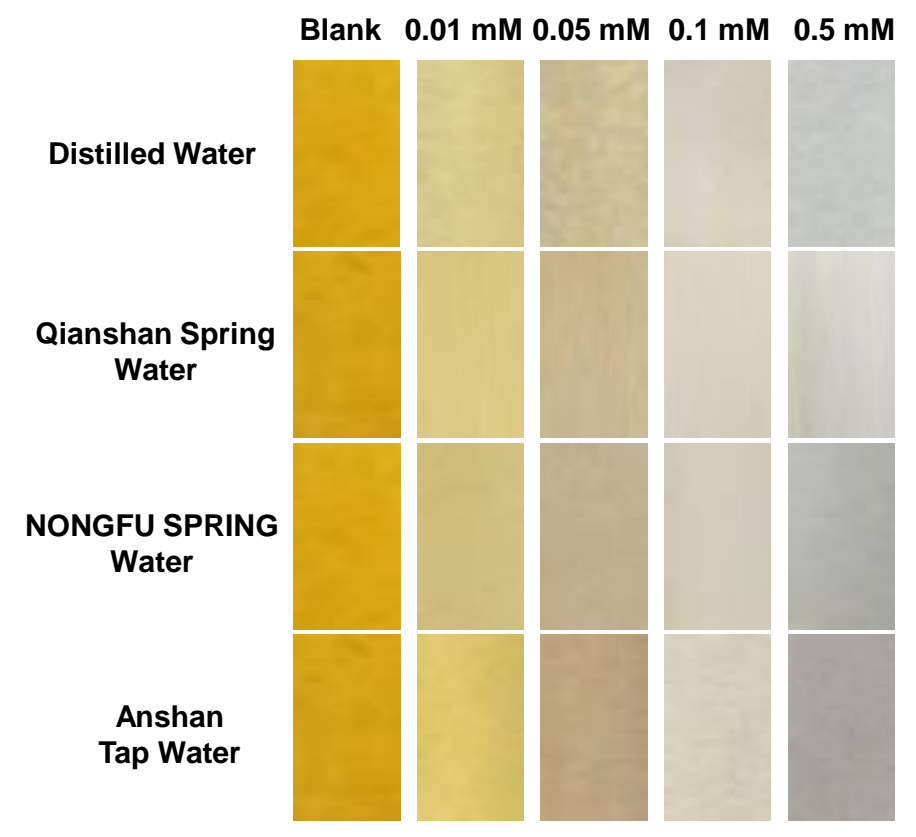

Figure 9. Color responses of L-ol-coated chromatography plates towards different concentrations of $\mathrm{HOCl}(0-0.5 \mathrm{mM})$ in several natural water samples.

\section{Experimental}

\subsection{Reagents and Materials}

1-Ethyl-2-methylquinolinium iodide was prepared according to our reported methods $[48,49]$. 2-Methylquinoline, iodoethane, 2-hydroxy-5-methoxy benzaldehyde were purchased from Aladdin reagent Co. (Shanghai, China). Anions (sodium salts), sodium hypochlorite $(\mathrm{NaOCl})$, 3-morpholinosydnonimine (SIN-1) $\left(\mathrm{ONOO}^{-}\right.$donor) were purchased from Alfa Aesar (Zhengzhou, China). The chromatography plates were purchased from commercial source with specifications of $25 \mathrm{~cm} \times 75 \mathrm{~cm}^{2}, 0.20-0.25 \mathrm{~mm}$ thickness. Unless otherwise stated, solvents and reagents were of analytical grade from commercial suppliers and were used without further purification. Deionized water was used throughout. 


\subsection{Apparatus}

${ }^{1} \mathrm{H}-\mathrm{NMR}$ and ${ }^{13} \mathrm{C}-\mathrm{NMR}$ spectra were recorded with an AVANCE600MHZ spectrometer (Bruker, Fällanden, Switzerland) with chemical shifts reported as ppm (in DMSO, TMS as internal standard). High resolution mass spectra (HR MS) were recorded on an Agilent 6530 QTOF spectrometer (Singapore). Absorption spectra were measured with a Perkin Elmer Lambda 900 UV/VIS/NIR spectrophotometer (Perkin Elmer, Waltham, MA, USA). Quartz cuvettes with a $1 \mathrm{~cm}$ path length and $3 \mathrm{~mL}$ volume were involved in fluorescence and UV-vis spectrum measurements. The $\mathrm{pH}$ was recorded by OHAUS ST3100 digital pH-meter (Changzhou, China).

\subsection{Synthesis and Characterization of $L-o l$}

1-Ethyl-2-methylquinolinium iodide $(0.299 \mathrm{~g}, 1 \mathrm{mmol})$ and 2-hydroxy-5-methoxy benzaldehyde $(0.152 \mathrm{~g}, 1 \mathrm{mmol})$ were dissolved in moderate amounts of absolute methanol, respectively. The mixture was then refluxed at $80^{\circ} \mathrm{C}$ for $8 \mathrm{~h}$ to form a dark green precipitate. The crude product was immediately filtered, and washed with cooled methanol to obtain L-ol in $73.4 \%$ yield. ${ }^{1} \mathrm{H}$ NMR (DMSO- $d_{6}, 600 \mathrm{MHz}$ ), $\delta(p p m) 10.29(\mathrm{~s}, 1 \mathrm{H}), 9.04(\mathrm{~d}, J=13.44 \mathrm{~Hz}, 1 \mathrm{H}), 8.54-8.59(2 \mathrm{H}), 8.39(\mathrm{t}, J=11.16 \mathrm{~Hz}, 1 \mathrm{H}), 8.25-8.29(\mathrm{~d}$, $J=23.64 \mathrm{~Hz}, 1 \mathrm{H}), 8.20(\mathrm{t}, J=11.19 \mathrm{~Hz}, 1 \mathrm{H}), 7.95(\mathrm{~d}, J=8.4,1 \mathrm{H}), 7.93(\mathrm{t}, J=3.66 \mathrm{~Hz}, 1 \mathrm{H}), 7.46(\mathrm{~d}, J=4.26$ $\mathrm{Hz}, 1 \mathrm{H}), 7.02(\mathrm{~d}, J=13.32 \mathrm{~Hz}, 1 \mathrm{H}), 6.94(\mathrm{~d}, J=13.32,1 \mathrm{H}), 5.12(\mathrm{q}, J=10.74 \mathrm{~Hz}, 2 \mathrm{H}), 3.79(\mathrm{~s}, 3 \mathrm{H}), 1.60(\mathrm{t}$, $J=10.65 \mathrm{~Hz}, 3 \mathrm{H}) .{ }^{13} \mathrm{C}$ NMR (DMSO- $\left.d_{6}, 125 \mathrm{MHz}\right), \delta($ ppm) 155.1, 152.9, 151.4, 143.1, 137.5, 134.4, 129.7, 126.3, 123.8, 121.2, 120.5, 119.8, 118.1, 117.3, 115.1, 112.7, 54.9, 46.0, 18.0, 13.1. HRMS-API (positive mode, $\mathrm{m} / \mathrm{z}$ ) for $[\mathbf{L}-o 1]^{+}$: calcd 306.1489, found: 306.1484 .

\subsection{Preparation of Stock Solutions of Probes and Analyte}

Stock solution of $\mathbf{L}-\mathbf{o l}$ at the concentration of $0.5 \mathrm{mM}$ was prepared by dissolving certain amounts of probes in DMF. For the detection of $\mathrm{HOCl}$ in buffer, the stock solution of $\mathbf{L - o l}$ was diluted into 20 mM PBS of pH 7.4 (DMF: $\mathrm{H}_{2} \mathrm{O}=7: 3, \mathrm{v} / \mathrm{v}$ ) for all spectrometric measurements. For the absorption response of $\mathbf{L - o l}$ to $\mathrm{HOCl}$ and $\mathbf{L}-o n e$ to $\mathrm{GSH}$, the spectra were recorded after mixing the analyte and probe for $5 \mathrm{~min}$ at room temperature. Solutions of a series of anions and biothiols $(20 \mathrm{mM})$ were freshly prepared by dissolving corresponding chemicals in deionized water. The ROS species were prepared in deionized water according to previous literature [50-53]. A stock solution of $\mathrm{HOCl}$ was prepared by diluting the commercial $\mathrm{NaOCl}$ solution and stored. Hydroxylradical $(\cdot \mathrm{OH})$ was generated in the Fenton system from ferrous ammonium sulfate and hydrogen peroxide. Superoxide anion radical $\left(\mathrm{O}_{2}{ }^{-}\right)$was generated from the xanthine-xanthine oxidase system. Singlet oxygen $\left({ }^{1} \mathrm{O}_{2}\right)$ was generated

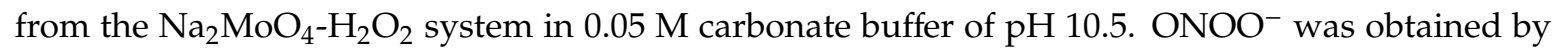
using SIN-1 as a donor. Hydrogen peroxide $\left(\mathrm{H}_{2} \mathrm{O}_{2}\right)$ was diluted immediately from a stabilized $30 \%$ solution, and was assayed using its molar absorption coefficient of $43.6 \mathrm{M}^{-1} \mathrm{~cm}^{-1}$ at $240 \mathrm{~nm}$.

\section{5. "Naked-Eye" Analysis of HOCl in Natural Water Samples by L-ol-Based Chromatography Plates}

The silica gel plates $(25 \times 75 \mathrm{~mm})$ were immersed into $50 \mathrm{~mL}$ dichloromethane solution of L-ol $(0.5 \mathrm{mM})$ for $10 \mathrm{~min}$. Then, the L-ol-coated silica gel plates were dried in air for further measurements.

Water samples were from four different sources: distilled water (DW), tap water (TW) from Anshan City (Liaoning Province, China), commercial drinking water (CW) (NONGFU Spring, China) and spring water (SW) from the Qianshan Mountain (Liaoning Province, China). Different stock solutions of $\mathrm{HOCl}$ were prepared using the above water samples. For "naked-eye" analysis of $\mathrm{HOCl}$ in the above natural water samples, the L-ol-coated chromatography plates were immersed in the $\mathrm{HOCl}$ aqueous solution with different concentrations for several seconds then dried in air. Then, the color changes of L-ol-coated chromatography plates were recorded under visible light. 


\section{Conclusions}

In summary, a novel $p$-methoxyphenol-based reversible colorimetric probe, L-ol, has been developed to selectively detect the $\mathrm{HOCl} / \mathrm{GSH}$ redox cycle in aqueous solution. By the reversible redox reaction, L-ol exhibited a switchable absorbance response along with a pale yellow to blue to pale yellow color change cycle. The redox-switchable responses of L-ol in ROS/GSH couple with excellent reversibility. The desirable features of $\mathbf{L}-\mathbf{o l}$ for the detection of $\mathrm{HOCl}$ in aqueous solutions, such as its high sensitivity and selectivity, observable color response and reliability at physiological $\mathrm{pH}$ enabled its application in the detection of $\mathrm{HOCl}$ in natural water samples. The easy-to-prepare L-ol-loaded chromatography plates have been successfully prepared. The preliminary investigations in natural water samples offer direct and immediate detection of $\mathrm{HOCl}$ in complex media in real time.

Supplementary Materials: The following are available online, Figure S1-3: NMR and HRMS characterizations of L-ol, Figure S4: The stability of L-ol, Figure S5,6: HRMS of L-ol sequential addition of HOCl and GSH, Figure S7: Linear relationship of L-ol with the concentration of HOCl. Figure S8: Absorption spectra of L-ol upon addition of various anions, Figure S9: Linear relationship of L-one with the concentration of GSH, Figure S10: UV-vis absorption spectra of L-one in the presence of various analytes, Figure S11: The color changes of L-one towards various competitive species.

Author Contributions: Q.M. and R.Z. conceived the ideas and designed the molecular probe wrote and revised the paper; Q.M, Z.Z. and R.Z analyzed the data, supervised the work; Q.H., F.Z., Y.W. and H.F. performed the experiments. Q.H. and F.Z. contributed equally to this work.

Funding: This research was funded by the Talent Program-Outstanding Youth Science Project, Liaoning (No. XLYC1807199), National Natural Science Foundation of China (No. 21601076), and the Australian Research Council (DE170100092).

Conflicts of Interest: The authors declare no conflict of interest.

\section{References}

1. Fruehauf, J.P.; Meyskens, F.L. Reactive oxygen species: A breath of life or death? Clin. Cancer Res. 2007, 13, 789-794. [CrossRef] [PubMed]

2. Wang, B.; Li, P.; Yu, F.; Chen, J.; Qu, Z.; Han, K. A near-infrared reversible and ratiometric fluorescent probe based on Se-BODIPY for the redox cycle mediated by hypobromous acid and hydrogen sulfide in living cells. Chem. Commun. 2013, 49,5790-5792. [CrossRef] [PubMed]

3. Curtis, M.P.; Hicks, A.J.; Neidigh, J.W. Toxic effect of gestational exposure to nonylphenol on F1 male rats. Chem. Res. Toxicol. 2011, 24, 418-428. [CrossRef] [PubMed]

4. Chiu, J.; Dawes, I.W. Redox control of cell proliferation. Trends Cell Biol. 2012, 22, 592-601. [CrossRef] [PubMed]

5. Xu, K.; Chen, H.; Tian, J.; Ding, B.; Xie, Y.; Qiang, M.; Tang, B. A near-infrared reversible fluorescent probe for peroxynitrite and imaging of redox cycles in living cells. Chem. Commun. 2011, 47, 9468-9470. [CrossRef] [PubMed]

6. Dooley, C.T.; Dore, T.M.; Hanson, G.T.; Jackson, W.C.; Remington, S.J.; Tsien, R.Y. Imaging dynamic redox changes in mammalian cells with green fluorescent protein indicators. J. Biol. Chem. 2004, 279, $22284-22293$. [CrossRef] [PubMed]

7. Winterbourn, C.C. Reconciling the chemistry and biology of reactive oxygen species. Nat. Chem. Biol. 2008, 4, 278-286. [CrossRef]

8. Nordberg, J.; Arner, E. Reactive oxygen species, antioxidants, and the mammalian thioredoxin system. Free Radic. Biol. Med. 2001, 31, 1287-1312. [CrossRef]

9. Feng, H.; Zhang, Z.Q.; Meng, Q.T.; Jia, H.M.; Wang, Y.; Zhang, R. Rapid Response Fluorescence Probe Enabled in vivo Diagnosis and Assessing Treatment Response of Hypochlorous Acid Mediated Rheumatoid Arthritis. Adv. Sci. 2018, 5, 1800397. [CrossRef]

10. Zhu, H.; Fan, J.L.; Wang, J.Y.; Mu, H.Y.; Peng, X.J. An “Enhanced PET"-Based Fluorescent Probe with Ultrasensitivity for Imaging Basal and Elesclomol-Induced HClO in Cancer Cells. J. Am. Chem. Soc. 2014, 136, 12820-12823. [CrossRef] 
11. Prokopowicz, Z.M.; Arce, F.; Biedron, R.; Chiang, C.L.L.; Ciszek, M.D.; Katz, R.; Nowakowska, M.; Zapotoczny, S.; Marcinkiewicz, J.; Chain, B.M. Hypochlorous acid: A natural adjuvant that facilitates antigen processing, cross-priming, and the induction of adaptive immunity. J. Immunol. 2010, 184, 824-835. [CrossRef] [PubMed]

12. Lv, J.; Wang, F.; Wei, T.; Chen, X. Highly Sensitive and Selective Fluorescent Probes for the Detection of $\mathrm{HOCl} / \mathrm{OCl}^{-}$Based on Fluorescein Derivatives. Ind. Eng. Chem. Res. 2017, 56, 3757-3764. [CrossRef]

13. Eugene, A.P.; Husam, M.A.; Stanley, L.H. Myeloperoxidase-generated oxidants and atherosclerosis. Biol. Med. 2000, 28, 1717-1725.

14. Pattison, D.I.; Davies, M.J. Evidence for Rapid Inter- and Intramolecular Chlorine Transfer Reactions of Histamine and Carnosine Chloramines: Implications for the Prevention of Hypochlorous-Acid-Mediated Damage. Biochemistry 2006, 45, 8152-8162. [CrossRef] [PubMed]

15. Zheng, L.; Nukuna, B.; Brennan, M.L.; Sun, M.; Goormastic, M.; Settle, M.; Schmitt, D.; Fu, X.; Thomson, L.; Fox, P.L.; et al. Apolipoprotein A-I is a selective target for myeloperoxidase-catalyzed oxidation and functional impairment in subjects with cardiovascular disease. J. Clin. Investig. 2004, 114, 529-541. [CrossRef] [PubMed]

16. Winterbourna, C.C.; Kettle, A. Biomarkers of myeloperoxidase-derived hypochlorous acid. J. Biol. Med. 2000, 29, 403-410. [CrossRef]

17. Winter, J.; Ilbert, M.; Graf, P.C.F.; Özcelik, D.; Jakob, U. The relationship between basic need satisfaction and emotional eating. Cell 2008, 135, 691-701. [CrossRef]

18. Wang, C.; Ji, H.; Li, M.; Cai, L.; Wang, Z.; Li, Q.; Li, Z. A highly sensitive and selective fluorescent probe for hypochlorite in pure water with aggregation induced emission characteristics. Faraday Discuss. 2017, 196, 427-438. [CrossRef]

19. Mari, M.; Morales, A.; Colell, A.; Garcia-Ruiz, C.; Kaplowitz, N.; Fernandez-Checa, J.C. Mitochondrial glutathione: Features, regulation and role in disease. Biochim. Biophys. Acta 2013, 1830, 3317-3328. [CrossRef]

20. Soni, D.; Gangada, S.; Duvva, N.; Roy, T.K.; Nimesh, S.; Arya, G.; Giribabu, L.; Chitta, R. Hypochlorite-promoted inhibition of photo-induced electron transfer in phenothiazineborondipyrromethene donor-acceptor dyad: A cost-effective and metal-free "turn-on" fluorescent chemosensor for hypochlorite. New J. Chem. 2017, 41, 5322-5333. [CrossRef]

21. Mari, M.; Morales, A.; Colell, A.; Garcia-Ruiz, C.; Fernandez-Checa, J.C. Mitochondrial glutathione, a key survival antioxidant. Antioxid. Redox Signal. 2009, 11, 2685-2700. [CrossRef] [PubMed]

22. Lou, Z.; Li, P.; Sun, X.; Yang, S.; Wang, B.; Han, K. A fluorescent probe for rapid detection of thiols and imaging of thiols reducing repair and $\mathrm{H} 2 \mathrm{O} 2$ oxidative stress cycles in living cells. Chem. Commun. 2013, 49, 391-393. [CrossRef] [PubMed]

23. Forman, H.J.; Zhang, H.; Rinna, A. Glutathione: Overview of its protective roles, measurement, and biosynthesis. Mol. Asp. Med. 2009, 30,1-12. [CrossRef] [PubMed]

24. Jiang, X.; Yu, Y.; Chen, J.; Zhao, M.; Chen, H.; Song, X.; Matzuk, A.J.; Carroll, S.L.; Tan, X.; Sizovs, A.; et al. Quantitative Imaging of Glutathione in Live Cells Using a Reversible Reaction-Based Ratiometric Fluorescent Probe. ACS Chem. Biol. 2015, 10, 864-874. [CrossRef] [PubMed]

25. Balaban, R.S.; Nemoto, S.; Finkel, T. Mitochondria, oxidants, and aging. Cell 2005, 120, 483-495. [CrossRef]

26. Banerjee, R. Redox outside the box: Linking extracellular redox remodeling with intracellular redox metabolism. J. Biol. Chem. 2012, 287, 4397-4402. [CrossRef] [PubMed]

27. Lomaestro, B.M.; Malone, M. Glutathione in health and disease: Pharmacotherapeutic issues. Ann. Pharmacother. 1995, 29, 1263-1273. [CrossRef]

28. Zuo, Y.; Zhang, Y.; Dong, B.; Gou, Z.; Yang, T.; Lin, W. Binding Reaction Sites to Polysiloxanes: Unique Fluorescent Probe for Reversible Detection of $\mathrm{ClO}^{-} / \mathrm{GSH}$ Pair and the in situ Imaging in Live Cells and Zebrafish. Anal. Chem. 2019, 91, 1719-1723. [CrossRef]

29. Lou, Z.; Li, P.; Han, K. Redox-Responsive Fluorescent Probes with Different Design Strategies. Acc. Chem. Res. 2015, 48, 1358-1368. [CrossRef]

30. Lv, X.; Yuan, X.; Wang, Y.; Guo, W. A naphthalimide based fast and selective fluorescent probe for hypochlorous acid/hypochlorite and its application for bioimaging. New J. Chem. 2018, 42, 15105-15110. [CrossRef]

31. Liu, S.-R.; Wu, S.-P. Hypochlorous Acid Turn-on Fluorescent Probe Based on Oxidation of Diphenyl Selenide. Org. Lett. 2013, 15, 878-881. [CrossRef] [PubMed] 
32. Manjare, S.T.; Kim, J.; Lee, Y.; Churchill, D.G. Facile meso-BODIPY Annulation and Selective Sensing of Hypochlorite in Water. Org. Lett. 2014, 16, 520-523. [CrossRef] [PubMed]

33. Lou, Z.; Li, P.; Pan, Q.; Han, K. A reversible fluorescent probe for detecting hypochloric acid in living cells and animals: Utilizing a novel strategy for effectively modulating the fluorescence of selenide and selenoxide. Chem. Commun. 2013, 49, 2445-24472. [CrossRef] [PubMed]

34. Liu, F.; Gao, Y.; Wang, J.; Sun, S. Reversible and selective luminescent determination of $\mathrm{ClO}^{-} / \mathrm{H}_{2} \mathrm{~S}$ redox cycle in vitro and in vivo based on a ruthenium trisbipyridyl probe. Analyst 2014, 139, 3324-3329. [CrossRef] [PubMed]

35. Zhang, B.; Yang, X.; Zhang, R.; Liu, Y.; Ren, X.; Xian, M.; Ye, Y.; Zhao, Y. Lysosomal-Targeted Two-Photon Fluorescent Probe to Sense Hypochlorous Acid in Live Cells. Anal. Chem. 2017, 89, 10384-10390. [CrossRef]

36. Yu, F.; Li, P.; Wang, B.; Han, K. Reversible Near-Infrared Fluorescent Probe Introducing Tellurium to Mimetic Glutathione Peroxidase for Monitoring the Redox Cycles between Peroxynitrite and Glutathione in vivo. J. Am. Chem. Soc. 2013, 135, 7674-7680. [CrossRef]

37. Zhang, W.; Liu, W.; Li, P.; Kang, J.; Wang, J.; Wang, H.; Tang, B. Reversible two-photon fluorescent probe for imaging of hypochlorous acid in live cells and in vivo. Chem. Commun. 2015, 51, 10150-10153. [CrossRef]

38. Venkatesan, P.; Wu, S.-P. A turn-on fluorescent probe for hypochlorous acid based on the oxidation of diphenyl telluride. Analyst 2015, 140, 1349-1355. [CrossRef]

39. Yue, Y.; Huo, F.; Yin, C.; Escobedoc, J.O.; Strongin, R.M. Recent progress in chromogenic and fluorogenic chemosensors for hypochlorous acid. Analyst 2016, 141, 1859-1873. [CrossRef]

40. Sun, Z.-N.; Liu, F.-Q.; Chen, Y.; Tam, P.K.H.; Yang, D. A highly specific BODIPY-based fluorescent probe for the detection of hypochlorous acid. Org. Lett. 2008, 10, 2171-2174. [CrossRef]

41. Kenmoku, S.; Urano, Y.; Kojima, H.; Nagano, T. Development of a highly specific rhodamine-based fluorescence probe for hypochlorous acid and its application to real-time imaging of phagocytosis. J. Am. Chem. Soc. 2007, 129, 7313-7329. [CrossRef] [PubMed]

42. Hu, J.J.; Wong, N.-K.; Gu, Q.; Bai, X.; Ye, S.; Yang, D. HKOCl-2 Series of Green BODIPY-Based Fluorescent Probes for Hypochlorous Acid Detection and Imaging in Live Cells. Org. Lett. 2014, 16, 3544-3547. [CrossRef] [PubMed]

43. Zhang, R.; Song, B.; Yuan, J. Bioanalytical methods for hypochlorous acid detection: Recent advances and challenges. Trends Anal. Chem. 2018, 99, 1-33. [CrossRef]

44. McCord, J.M. Free radicals and inflammation: Protection of synovial fluid by superoxide dismutase. Science 1974, 185, 529-531. [CrossRef] [PubMed]

45. Cui, K.; Zhang, D.; Zhang, G.; Zhu, D. A highly selective naked-eye probe for hypochlorite with the p-methoxyphenol-substituted aniline compound. Tetrahedron Lett. 2010, 51, 6052-6055. [CrossRef]

46. Zhang, W.; Guo, C.; Liu, L.; Qin, J.; Yang, C. Naked-eye visible and fluorometric dual-signaling chemodosimeter for hypochlorous acid based on water-soluble $p$-methoxyphenol derivative. Org. Biomol. Chem. 2011, 9, 5560-5563. [CrossRef] [PubMed]

47. Wang, Q.; Liu, C.; Chang, J.; Lu, Y.; He, S.; Zhao, L.; Zeng, X. Novel water soluble styrylquinolinium boronic acid as a ratiometric reagent for the rapid detection of hypochlorite ion. Dyes Pigments 2013, 99, 733-739. [CrossRef]

48. Feng, H.; Meng, Q.T.; Wang, Y.; Duan, C.C.; Wang, C.P.; Jia, H.M.; Zhang, Z.Q.; Zhang, R. Responsive Fluorescence Probe for Selective and Sensitive Detection of Hypochlorous Acid in Live Cells and Animals. Chem. Asian J. 2018, 13, 2611-2618. [CrossRef] [PubMed]

49. Zhou, F.; Sultanbawa, Y.; Feng, H.; Wang, Y.L.; Meng, Q.T.; Wang, Y.; Zhang, Z.Q.; Zhang, R. A New Red-emitting Fluorescence Probe for Rapid and Effective Visualisation of Bisulfite in Food Samples and Live Animals. J. Agric. Food Chem. 2019, 67, 4375-4383. [CrossRef]

50. Zhang, R.; Ye, Z.; Wang, G.; Zhang, W.; Yuan, J. Development of a Ruthenium (II) Complex Based Luminescent Probe for Imaging Nitric Oxide Production in Living Cells. Chem. Eur. J. 2010, 16, 6884-6891. [CrossRef]

51. Setsukinai, K.; Urano, Y.; Kakinuma, K.; Majima, H.J.; Nagano, T. Development of Novel Fluorescence Probes That Can Reliably Detect Reactive Oxygen Species and Distinguish Specific Species. J. Biol. Chem. 2003, 278, 3170-3175. [CrossRef] [PubMed] 
52. Xiao, Y.; Zhang, R.; Ye, Z.; Dai, Z.; An, H.; Yuan, J. Lanthanide complex-based luminescent probes for highly sensitive time-gated luminescence detection of hypochlorous acid. Anal. Chem. 2012, 84, 10785-10792. [CrossRef] [PubMed]

53. Hu, J.J.; Wong, N.-K.; Ye, S.; Chen, X.; Lu, M.-Y.; Zhao, A.Q.; Guo, Y.; Ma, A.C.-H.; Leung, A.Y.-H.; Shen, J.; et al. Fluorescent Probe HKSOX-1 for Imaging and Detection of Endogenous Superoxide in Live Cells and in vivo. J. Am. Chem. Soc. 2015, 137, 6837-6843. [CrossRef] [PubMed]

Sample Availability: Molecular probe L-ol is not available from the authors.

(C) 2019 by the authors. Licensee MDPI, Basel, Switzerland. This article is an open access article distributed under the terms and conditions of the Creative Commons Attribution (CC BY) license (http://creativecommons.org/licenses/by/4.0/). 